Inga Gluszek

https://doi.org/10.26485/AAL/2020/66/11

\title{
A MINIATURE TERRACOTTA FIGURINE FROM NIKONION
}

\begin{abstract}
The terracotta figurine which is the subject of this paper was found during excavations in Nikonion in 2011. The article seeks to analyse the figurine in order to suggest an origin for the prototype of the terracotta representation, considering that it constitutes a relatively schematic depiction, that it might be late Classical in date judging by the archaeological context.
\end{abstract}

Key words: ancient Nikonion, terracotta figurines

\section{MINIATUROWA FIGURKA TERAKOTOWA Z NIKONION}

\begin{abstract}
ABSTRAKT Terakotowa figurka, będąca przedmiotem niniejszego artykułu została znaleziona podczas badań archeologicznych prowadzonych w Nikonion w 2011 roku. W artykule zaprezentowano analizę zabytku, której celem było wskazanie proweniencji prototypu zastosowanego dla terakoty. Biorąc pod uwagę kontekst archeologiczny znaleziska oraz stosunkowo schematyczny sposób przedstawienia, terakotę można wiązać z późnoklasycznym horyzontem stylistycznym.
\end{abstract}

Słowa kluczowe: antyczne Nikonion, terakotowe figurki

Archaeological context

In 2011, at the site in the village of Roksolany (Ukraine), which has been identified with the ancient Nikonion, a terracotta figurine depicting a female figure was found. The figurine was discovered in one of the rooms of a residential building located in the northern part of the site. The residential complex was explored by a Polish-Ukrainian research team in the years 2009-2011. ${ }^{1}$

The figurine is damaged. The head is broken off at the level of neck, and the lower part of the statuette from the knees down. the statuette. The figurine is made of bright orange coloured clay on the outside, and bright red with a pink tinge where it is broken (50YR 26/461-60YR 24/439).

1 I would like to take this opportunity to thank the researchers from Odessa, Natalia Michailovna Sekerskaya and Sergey Borysovich Okchotnikov, for their support and fruitful cooperation. Words of thankfulness should also go to professor Mariusz Mielczarek, who began and still continues to conduct archaeological research in the northern Black Sea region, his support and encouragement were crucial for the Author in the process of writing of that article.
The clay is medium-grained with visible inclusions of limestone and quartzite, and is well-fired. On the outer surface, there are traces of a thin, white engobe. The preserved terracotta fragment is $3.6 \mathrm{~cm}$ high; $2.4 \mathrm{~cm}$ wide and $2.3 \mathrm{~cm}$ long.

The description of stylistic features of the terracotta figurine

The figurine is of a female standing upright, with her right hand raised to the level of her chest, clenched, with a flower, fruit, or bird inside. The left arm is slightly bent, and falls freely along the body, the hand resting in front on the figure's left leg (Fig. 1,2). The quality of workmanship and the state of preservation are very low, so it is not possible to judge if the figure supports the robe with her left hand, which would be indicated by the fall in the folds of the garment. The woman is dressed in a chiton and a himation slung over her right arm. Some small rounded folds of the fabric are shown only on the hem of the cloak, which is slung over the right shoulder. On the rest of the surface, no details of drapery have been observed; however, such anatomical features as the protruding left leg, 


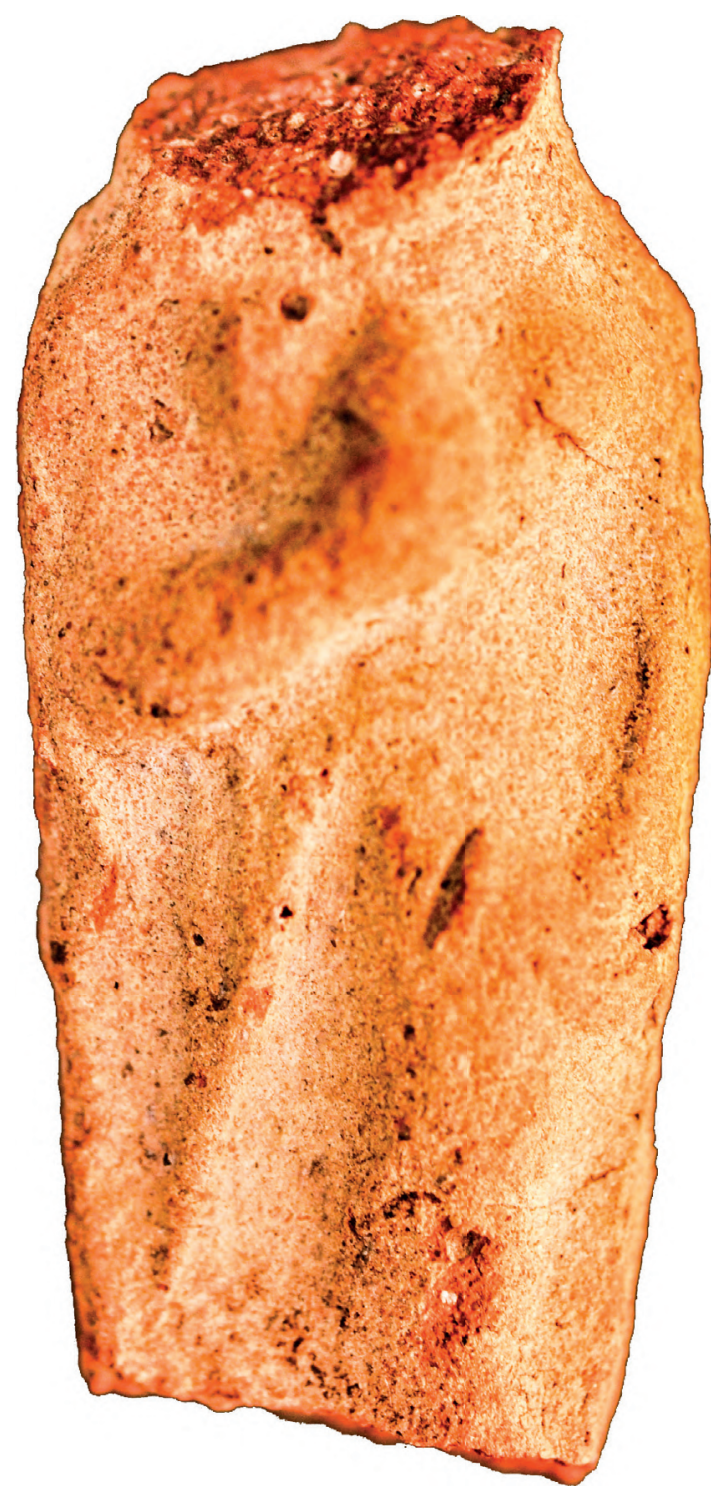

Fig. 1. The depiction of terracotta figurine, frontal side. Photography by E. Kozłowska

and the woman's breasts are silhouetted under the fabric. The back side is presented schematically. The hair falling on the woman's shoulders are shown as a smooth surface without any additional details. Also, the waist and the bent elbow of the woman's left hand are clearly visible (Fig. 3).

The figurine is made from a two-part mould, it has schematic, detail-free modelling, and there are seams on both sides, left by the mold that was used to make the terracotta.

Some artefacts were found along with the figurine. These included a fragment of a black-gloss cup-skyphos, a fragment of the rim and the neck of an amphora from Heraclea Pontica with a partially preserved stamp, and a bronze object in the form of a $0.4 \times 0.6 \mathrm{~cm}$ thick wire, coiled in a loop. The fragment of a cup-skyphos represents a shape characteristic for the first quarter of the 4th century
$\mathrm{BC},{ }^{2}$ and the amphora from Heraclea Pontica belongs to the type II according to Monahov, also dates to the first decades of the 4 th century BC. ${ }^{3}$

Simple moulds began to be used for the production of clay figurines already in the Geometric period, The use of moulds greatly improved the production process in Greece, and this skill had been derived from the Middle East through the territories of Cyprus or Syria and has been employed in Greek workshops in Asia Minor, Rhodes, and Crete from the 7th century BC. The development of specialized forms in the Classical period allowed for the spread of terracotta products in various manufacture centres. The use of moulds for the production of terracotta figurines became common in the 5th century BC, whereas the peak of the development of the craftsmen's skills in this area falls in the late 4th century BC and the Hellenistic period until the 2 nd century BC. ${ }^{4}$ In order to make a terracotta mould, a clay figurine was first created by hand and it was referred to as a prototype, archetype, or patrix. Then a clay or plaster mould was made from such a prototype. Plaster moulds were used, among other places, in Athens and Egypt until the $3 \mathrm{rd}^{5}$ or 2 nd century BC. ${ }^{6}$ Figures cast from the first mould could be used to make another, or several other, moulds. ${ }^{7}$ This process could be repeated several times so that a series of successive terracotta figurines were created, fashioned from moulds taken from already existing figurines. ${ }^{8}$ The ongoing process of copying resulted in a gradual decrease in the height of the figurines and a reduction of the details of their modelling. ${ }^{9}$ Terracotta figurines moulded in forms taken off from prototypes make the first generation of the series. Both prototypes and figurines could be exported and reproduced in craft workshops in different parts of the Greek world. This process explains the existence of identical statuettes belonging to the same generation. It also explains the existence of simpler representations of well-crafted prototypes which can be dated a far later period than the first figurine made. Terracottas with a schematic appearance indicate that they were made

\footnotetext{
2 Agora 12: 110-111, fig. 6, 605.

3 Monahov 2003: 134-135, tab. 94-97.

4 Müller 1990: 439; Burn, Higgins 2001: 20.

5 Acheilara 2006: 35-38.

6 Burn, Higgins 2001: 19.

7 Uhlenbrock 1990: 16; Burn, Higgins 2001: 18-19.

8 Muller 1997: 437-463, Muller 2000: 92-96. The
} criticism of the method was presented by: Nicholls 1982 : 89-122.

9 Muller 2014: 67-68. 


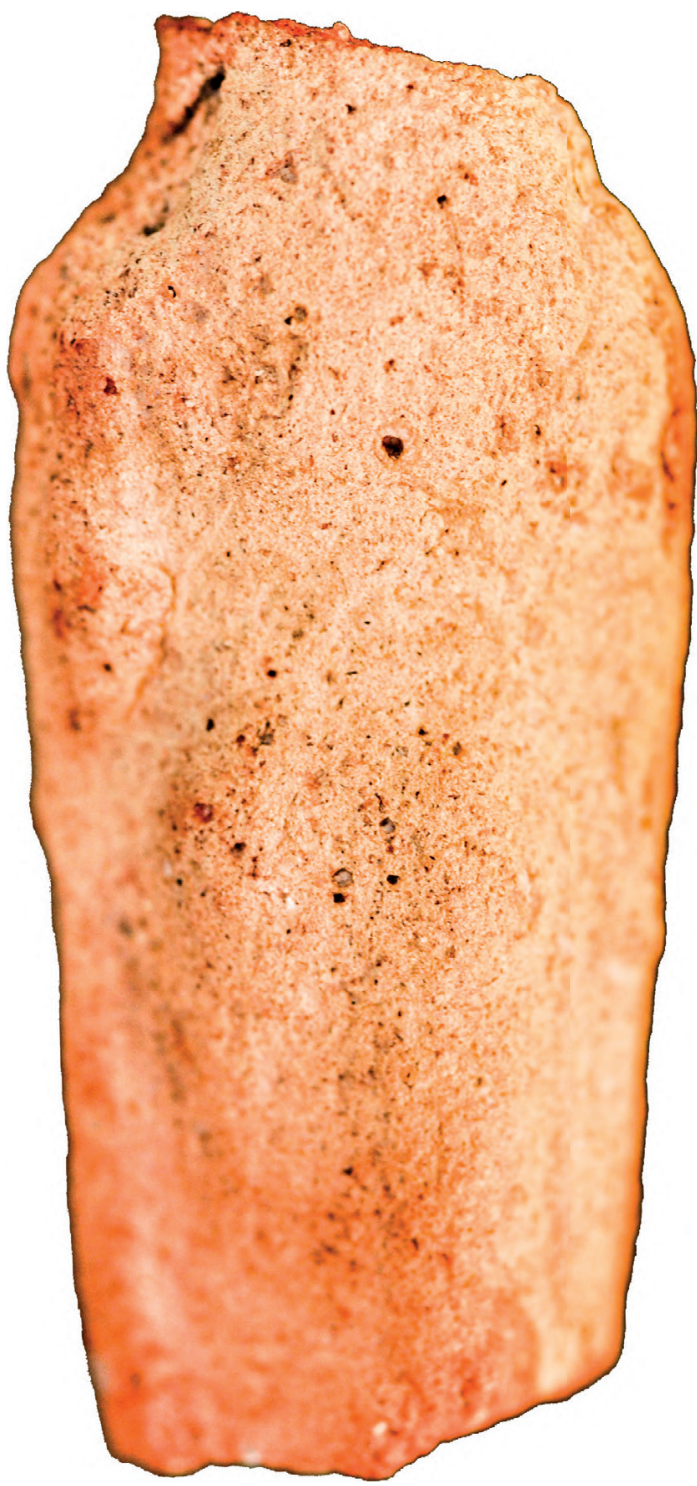

Fig. 2. The depiction of terracotta figurine, back side. Photography by E. Kozłowska

by impressing the mould from another terracotta figurine (already with a simplified silhouette), thus resulting in further softening of the details; or that they were created from an initial mould already devoid of many details such as fabric folds, characteristics of the anatomy, or facial features. This phenomenon is well represented by the finds from Lachidia, ${ }^{10}$ which include, among others, the depiction of a woman dressed in a peplos, but with minimally marked elements of the composition, captured in a geometric block. The schematic but still quite detailed treatment of the back side of the figurine, with the hair outlined, and the waist as well as the body modelling, points to the references to terracotta style of the Archaic period, when many bottles and figurines were presented with

10 Dörpfeld 1927: beliage 78.a. a precisely outlined back of the outfit and hairstyle. This is characteristic of the Eastern Greek terracotta statuettes ${ }^{11}$. Schematic representation suggests long-term use of the type by retrieving subsequent forms from prototypes widespread in Eastern Greek areas. ${ }^{12}$ The terracotta from Nikonion might be considered as an another example of the sustained use and exploitation of the another kind of prototype, which can be pointed out among the clay figurines characteristic for the late Archaic Period.

The analysis of the style depiction of the terracotta figurine

The representation known from Nikonion find can by classified as a schematic representation belonging to the Aphrodite Group which appeared in Greek coroplastic art in the Archaic Period ${ }^{13}$.

The very close composition but expressed with much more precision and richer in details is a terracotta figurine from the British Museum. The figure of a standing woman is $13 \mathrm{~cm}$ high, wears chiton and himation with the right arm free and holding a dove in her the right hand, her left arm lowered with the hand resting in front on her leg. The terracotta was recognised as being of Rhodian production, ${ }^{14}$ and might be considered as a prototype for the later generation of terracottas resulting in the schematic and simple figure as typified by the example from Nikonion.

Another close analogy for the find from Nikonion comes in the form of a wholly preserved terracotta of a standing woman (11 cm high) who holds her right hand at her chest, and with her left hand supports her clothing. The figurine was found at $\mathrm{Cos}$ and is dated to the early 5 th century BC. ${ }^{15}$

The Nikonion terracotta can be compared with an artefact from the collection in Copenhagen. The fragmentally preserved terracotta is of a woman wearing a chiton and himation, she has one hand raised to her chest in which she holds a bird. The other hand lies along her side, she holds the edge of her clothing by this hand. The depiction and style of this terracotta figurine is more detailed than the features of the Nikonion example, but the general idea of the clothing and how the edge

11 Köster 1926: 39, taf. 14.

12 Beschtsi 2017: 41-44, fig. 2, Müller 2017: 61, fig. 1; Müller 2014: 67-68.

13 Higgins 1967: 32-35

14 Higgins 1969: 60, no 114.

15 op. cit. pl. 52, 343. 


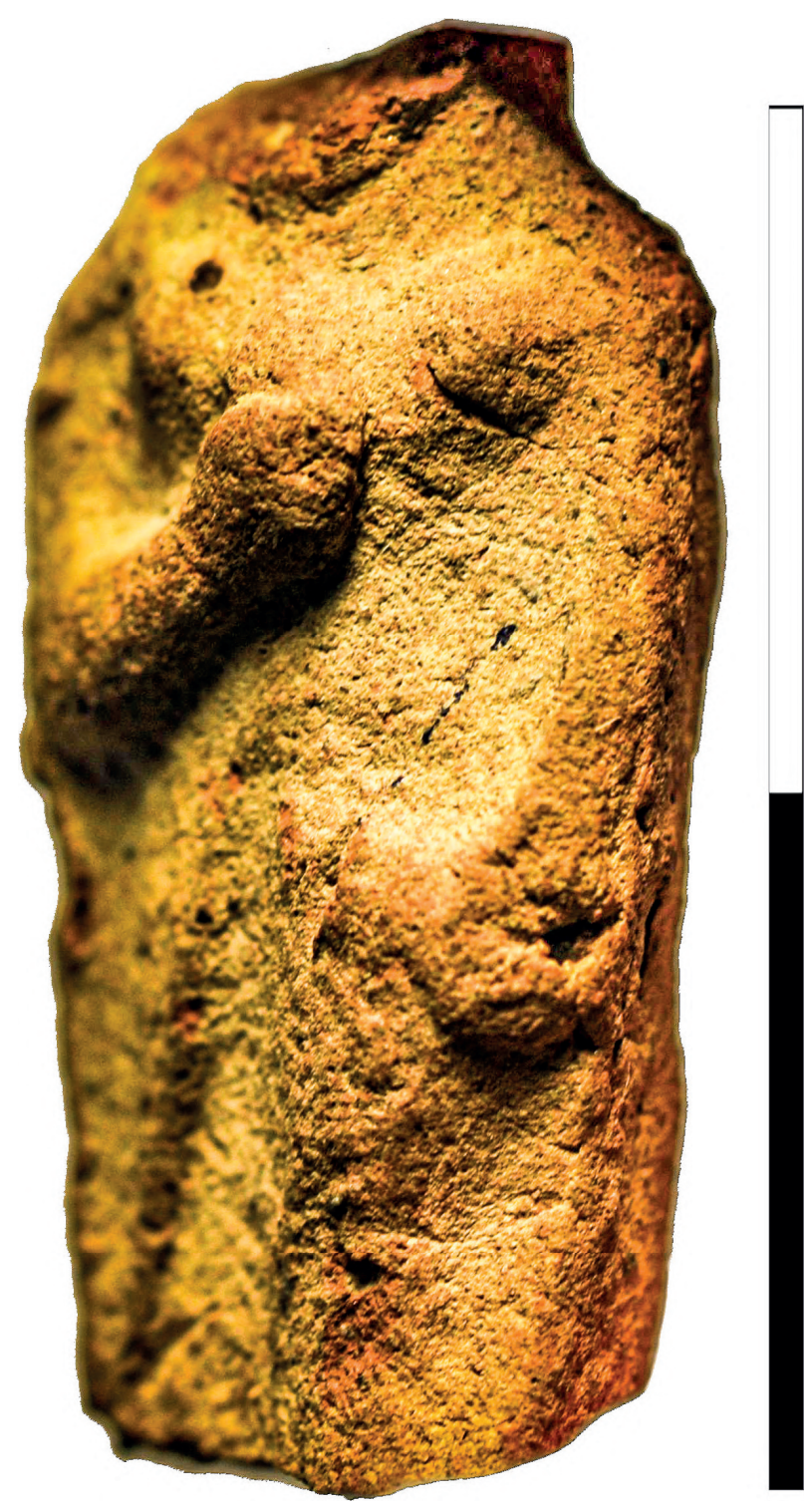

Fig. 3. The depiction of terracotta figurine, details of the frontal side.

Photography by E. Kozłowska

of the himation falls down at the right side of the woman's body (Fig. 4) are very suggestive, and comparable to the style and to the treatments of details which we find on the find from Nikonion This analogous figure is dated to the late archaic period. ${ }^{16}$

In general, the figurine from Nikonion repeats the pattern of depiction known from an archaic figurine from the Robinson Collection. This terracotta figurine was found in Olynthus. ${ }^{17}$ The statuette has her right arm raised with the hand at the level of the chest, whereas the left hand is slightly bent and supports the chiton. The figurine does not hold anything in its hand. It has its left leg placed forward

16 Breitenstein 1941: pl. 23. 239.

17 Olynthus XIV: 157-158, pl. 61. 186A. and the chiton flaps slung over the right arm. The folds of its drapery display a different pattern when compared to the figure from Nikonion, but despite the fact that they are poorly defined, they were supposed to add delicacy to the composition to the Olynthus terracotta.

A figurine with a similar style of depiction to the Nikonion figurine is a statuette from Boeotia holding a flower in her hand resting on her breast. ${ }^{18}$ The figurine has been described as Kore, the daughter of Demeter, and the flower in her hand indicates the springtime that Kore-Persephone brings with her. Another figurine in this style is from Lindos. ${ }^{19}$ Both terracotta statuettes are dated to the end of the 6 th or the beginning of the 5 th centuries BC. ${ }^{20}$ The group of Lindos figures represents a refined and detailed type of composition. ${ }^{21}$ The making of successive moulds from the terracotta figurines of this workshop led to a degeneration (simplification) of the composition as witnessed in the case of the statuette from Nikonion. The figurine is devoid of detailed modelling of robes, it is flat and blocklike. The hands are marked so schematically it is difficult to judge whether the woman holds something in her hand or not. Comparing the examples from Lindos to the Nikonion statuette, the difference is that the left hand is slightly detached from the body, and not, as is the case with the Nikonion terracotta, placed alongside the figurine's thigh. The Lindos figurines are of various sizes, from 14 to $8 \mathrm{~cm}$ high and are dated back to the period 520$400 \mathrm{BC}^{22}$

Some similarities in the arrangement of the robes, hands, and proportions are visible wheh we compare the terracotta from Nikonion to the figurine from the Archaeological Museum of Komotini. The statuette comes from the furnishings of a tomb from the site of Molyvos. ${ }^{23}$ The figurine is larger (h. $16 \mathrm{~cm}$ ) and represents a development of the style characteristic of the Aphrodite Group terracottas. The characteristics of the clay led to the figurine being classified as a product of Thasos. Additionally, there are other terracotta finds representing a similar style of depiction found at other sites on the island. The figurines belong to the Aphrodite Group and have been widely distributed and copied throughout Ionia and other parts

18 Schneider-Lengyel 1936: 18, fig. 27.

19 Lindos I: pl. 97, no 2146-2149; Winter: 44: 4, 8.

20 Olinthus XIV: 158.

21 Lindos I: pl. 97, no 2148, 2147, 2149.

22 Lindos I: 520, pl. 97, no 2147, 2148, 2149.

23 Adam-Veleni., Koukouvou, Palli, Stefani, Zografou (eds.) 2017: 362, no. 421. 


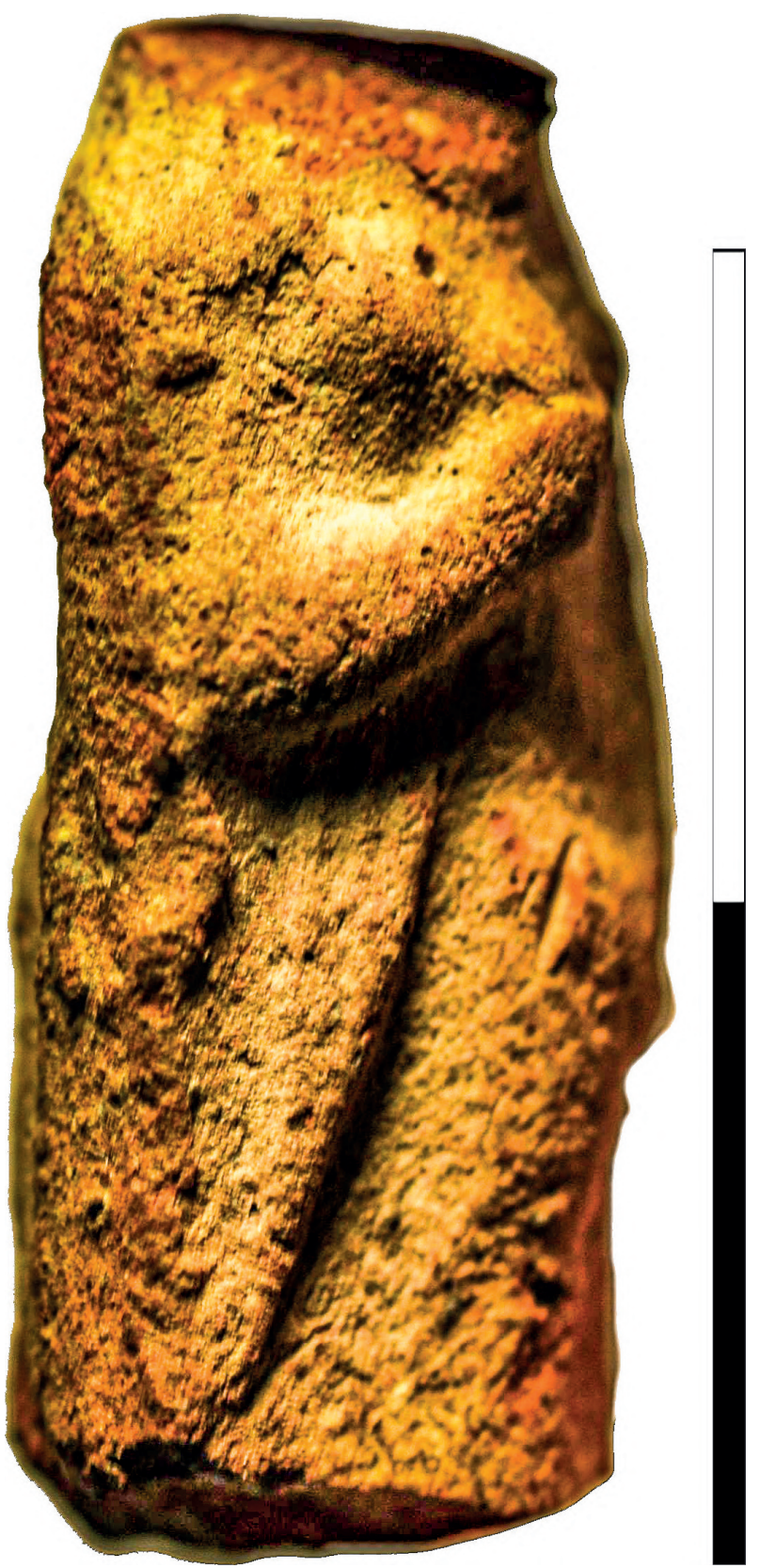

Fig. 4. The depiction of terracotta figurine, details of the side and frontal surface.

Photography by E. Kozłowska

of Greece. Figurines of this type are often found in sanctuaries of female deities or in tombs, they could also be used in household altars associated with female deity cults. The find from Molyvos has been compared with others from Skerlou, and an artefact from the Cleveland Museum of Art, based on which it has been dated to the end of the 6 th or the beginning of the 5 th century BC. ${ }^{24}$

The prototype of the Nikonion figurine can also be found in an assemblage from Catania,

24 Grigoriadou 2014: no. 2; Cleveland Museum of Art: no 1926.518 za: Adam-Valeni 2017: 362, no. 421. which is dated to the last quarter of the 6th to the first quarter of the 5 th century $\mathrm{BC} .{ }^{25} \mathrm{~A}$ comparable depiction of a standing woman wearing a chiton and himation covering the right arm of the woman is found in a terracotta figurine dating to 500-490 $\mathrm{BC}$ from the Louvre. She might hold a flower in her right hand, the left one is supporting her dress. There are also another two examples from the Louvre which can be dated to the end of 6th and the first decade of a 5 th centuries $\mathrm{BC}$ which exhibit similarities with the terracotta from Nikonion ${ }^{26}$.

Examples of figurines known from excavations carried out in the area of the Artemision in Thasos also reflect the basic features of composition and clothing characteristic of the Nikonion terracotta. Noteworthy is the placing of the left hand on the thigh as if the figure was holding the gathered and raised folds of the fabric. Such figurines from the Artemision in Thasos are included in the V-B group dated to $530-520 \mathrm{BC} .{ }^{27}$ The V-B group is referred to as North Ionian-Aeolian terracotta figurines ${ }^{28}$.

Further examples which might be considered as prototypes for Nikonion terracotta were classified as terracottas of Post-Aphrodite Group dated to the beginning of the 5th century BC. The Group is considered as a further development of the Aphrodite Group and has been connected with Ionian, centres especially with Rhodes. But as Fahri Işık pointed out there is external influence connecting the Post-Aphrodite Group type with a terracotta prototype derived from Athens. ${ }^{29}$

The fragment from Nikonion also shows similarities in terms of composition, style, modelling, and the level of schematic approach to the figurines found in the Kerameikos. The first of these examples which can be considered as comparative has a different modelling of the upper body, starting from the height of the breast to the flat back of the figurine. This suggests that the terracotta could have been intended to be placed in a recess, or to be propped up against a wall. The second example from the Kerameikos draws our attention due to the position of the left hand, which rests in front on the thigh of the figurine's protruding $\operatorname{leg}^{30}$.

25 Pautasso 2015: fig 1, K 517.

26 Mollard-Besques 1954: 58, pl. XXXVIII, B 353; p. 52-53, pl. XXXIV, 348, 340.

27 Huysecom-Haxhi 2009: 423, 434-437, pl. 65. 1769.

28 Op. cit.: 341.

29 Işık 2000: 336-337.

30 Kerameikos XV: taf. 8. 31.2; as indicated by the authors of the study of finds from Athens, a similar arrangement of hands is presented in the figure from: 
The figurines are classified as the Acropolis Kora type statuettes and are assigned to an Attic workshop. The arrangement of the costume is described as the Ionian chiton, which was widespread among the terracotta figurines in the classical period..$^{31}$ The first example is dated to roughly $490 \mathrm{BC}$, while the second to the beginning of the 5th century BC. Both figurines have a more detailed modelling and refined style than the Nikonion figurine, so they can be considered as prototypes for subsequent local terracotta productions in the East Greek (Ionia) or Black Sea lands.

Among the terracotta finds from Greek sites on the northern coast of the Black Sea, there are groups of finds dating back to the Late Archaic and Early Classical periods, which show a standing or sitting female figure with a similarly schematic compositional approach. Among these finds, noteworthy is an example depicting a standing figure, dressed in a chiton and himation with a pigeon in her hand which is raised to the level of her chest. The terracotta comes from Panticapaeum and is dated to the end of the 6th or to the beginning of the 5th century BC. ${ }^{32}$ Another figurine from Panticapaeum displays a type similar to the composition of the Nikonion one. The terracotta figurine shows a female silhouette with her left hand along the body, in a gesture suggesting supporting the draped robe, and the right hand holding a dove at chest height. The artefact is dated to the end of the 6 th or to the beginning of the 5 th century BC..$^{33}$

Among the terracotta figurines from Berezan, dated to the second half of the 6th century BC, there is a terracotta showing a standing female figure holding her arms along her body, and a representation of a bird sitting at the figure's feet. The style of the figurine indicates that it belongs to the Archaic period. ${ }^{34}$ These figurines depict standing figures, but none of them are executed in a style similar to the representation known from Nikonion. Besides, all figurines are more detailed, better crafted, and are larger in size than the Nikonion find.

Due to the features of the depiction and the context of the Nikonion find, the terracotta can be associated with the domestic cults of female deities, perhaps the cult of Aphrodite, ${ }^{35}$ Demeter, or Hera. $^{36}$

Goldman 1940: fig. 169. 2 (44).

31 Schneider-Lengyel 1936 : 19,fig. 27.

32 Kobylina 1961: 39-40, tab. IV.

33 op.cit., 39, tab. IV, 1.

34 Kopejkina 1977: 96, ris. 8a.

35 Savel'eva 2018: 41-42, tab. 1, 4.

36 LIMC: Demeter, Hera.

\section{Conclusions}

The figurine has an individual character, which makes it difficult to carry out comparative tests on its technological features, such as the colour and quality of clay, which would allow one to determine their centre of their production. Terracotta moulds and finds known as products of local workshops are confirmed in Olbia. ${ }^{37}$ However, they are different in type and style of depiction. The quality of workmanship, the level of detail found on the terracotta, and its composition, as well as its small size, suggest a comparatively late date for the figurine. In spite of the lack of detailed treatment of the surface, the style of the figurine can be linked with more carefully made earlier examples. These latter are characteristic for the workshops from the northern areas of Ionia, dated to the end of the 6th or the beginning of the 5th century BC. The context of the find suggests a very late chronology for the find of the first half of the 4th century BC. This is unexpected for a terracotta figurine representing this particular style, but is plausible and understandable considering the character of the private space of the archaeological context, the simple expression of the style, and small size of the terracotta, which suggests a significant number moulds taken from the prototype, and their long term use before this version of appeared.

\section{Abbreviations}

Agora 12 - Sparkes B.A., and Talcott L. The Athenian Agora, Vol. 12, Black and Plain Pottery of the 6th, 5th and $4^{\text {th }}$ Centuries B.C. Part 1, 2, Princeton: The American School of Classical Studies at Athens, 1972.

Olynthus XIV - Robinson D. M., Excavations at Olynthus. Part XIV. Terracottas, Lamps and Coins found in 1934 and 1938, John Hopkins University Studies in Archaeology, no. 39, Baltimore, 1952

Kerameikos XV - Kunze-Götte E, Kerameikos XV. Terrakotten, Berlin: Deutsches Archäologisches Institut, 1997.

LIMC - Lexicon Iconographicum Mythologiae Classicae, Artemis: Verlag, vol. 2, 1988, vol. 3, 1986 
Lindos I $\quad-$ Blinkenberg C., Lindos. Fouilles et recherches 1902-1914 I. Les petitsobjets, Lindos: Walter de Gruyter 1931.

Literature

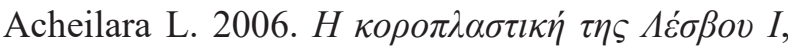
Mytilếnē: Ypourgeío Politismoú, $\mathrm{K}^{‘}$ Ephoreía Proïstorikốn kai Klasikốn Archaiotêtōn.

Adam-Veleni P. 2017. Koukouvou A., Palli O., Stefani E., Zografou E. (eds.), Figurines. A Microcosmos of Clay, Catalogue of the temporary exhibition at the Archaeological Museum of Thessaloniki, Thessaloniki: Archaeological Museum of Thessaloniki.

Beschtsi K. 2017. Production techniques, in: Adam-Veleni P., Koukouvou A., Palli O., Stefani E., Zografou E. (eds.), Figurines. A Microcosmos of Clay, Catalogue of the temporary exhibition at the Archaeological Museum of Thessaloniki, Thessaloniki: Archaeological Museum of Thessaloniki.

Breitenstein N. 1941. Danish National Museum. Catalogue of Terracottas, Cypriote, Greek, Etrusco-Italian and Roman, Copenhagen: Munksgaard.

Burn L., Higgins R. 2001. Catalogue of Greek Terracottas in the British Museum III, London: British Museum Press.

Dörpfeld W. 1927. Alt-Ithaka. Ein Beitrag zur Homerfrage, Studien und Ausgrabungen auf der Insel Leukas-Ithaka München-Gräfelfing.

Goldman H. 1940. The Acropolis of Halae, Hesperia. The Journal of the American School of Classical Studies at Athens 9, no 4, 381-514.

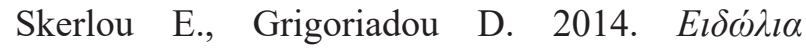

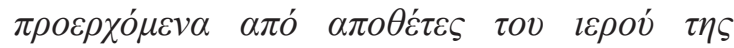

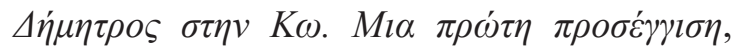

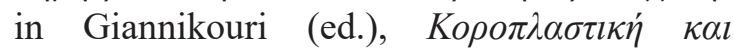

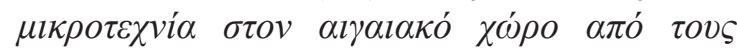


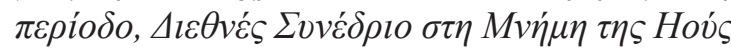

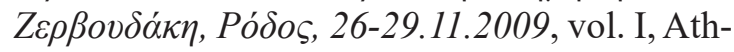
ens, 119-148.

Higgins R.A. 1967. Greek Terracottas, London: Methuen.

Higgins R.A. 1969. Greek Terracotta Figures, London: British Museum Press.

Huysecom-Haxhi S. 2009. Les figurines en terre cuite archaïques de l'Artémision de Thasos: artisanat et piété populaire. Études Thasiennes 21, Athens: École française d'Athènes.

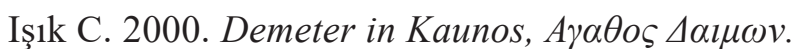
Mythes et cultes. Études d'iconographie en l'honneur de Lilly Kahil, Bulletin de correspondance hellénique. Suppléments 38, 229240.

Kobylina M.M. 1961. Terrakotovye statuetki Pantikapeâ i Fanagorii, Moskva: Izd-vo Akademii Nauk SSSR.

Kopejkina L.V. 1977. Kompleks arkhaicheskikh terrakot s Berezani, Vestnik Drevnej Istorii 1977, no 3, 130-132.

Köster A. 1926. Die griechischen Terrakotten, Berlin.

Mollard-Besques S. 1954. Catalogue raisonné des figurines et reliefs en terre cuite grecs, étrusques et romains. I, époques préhelléniques, géométrique, archaïque et classique, Paris Editions des musées nationaux.

Monahov S.Ju. 2003. Grecheskie Amfory v Prichernomor'ye, Moskva-Saratov: Izdatel'stvo "Kimmerida" Izdatel'stvo Saratovskogo universiteta.

Müller C. 1990. Kindheit und Jugend in der griechischen Frühzeit. Eine Studie zur pädagogischen Bedeutung von Riten und Kulten, Giessen: Focus kritische Universität.

Muller A. 1997. Description et analyse des productions moulées: proposition de lexique multilingue, suggestions de méthode, in: A. Muller (ed.), Le moulage en terre cuite dans l'Antiquité: création et production dérivée, fabrication et diffusion (Colloque, Lille, décembre 1995), Lile: Presses Universitaires du Septentrion.

Muller A. 2000. Artisans, techniques de production et diffusion: le cas de la coroplathie, in: F. Blondé, A. Muller (eds), L'artisanat en Grèce ancienne. Les productions, les diffusions (Colloque, Lyon, décembre 1998), Villeneuve d'Ascq: Université Charles de Gaulle-Lille.

Muller A. 2014. L'atelier du coroplathe: un cas particulier dans la production céramique grecque, Perspective. La revue de l'INHA 2014, 1, p. 63-82.

Muller A. 2017. The coroplastic workshops of Thasos, in: Adam-Veleni P., Koukouvou A., Palli O., Stefani E., Zografou E. (eds.), Figurines. A Microcosmos of Clay, Catalogue of the temporary exhibition at the Archaeological Museum of Thessaloniki, Thessaloniki: Archaeological Museum of Thessaloniki.

Nicholls R.V. 1982. Two Groups of Archaic Attic Terracottas, in: D. Kurtz, B. Sparkes (eds), The Eye of Greece. Studies in the Art of Athens Presented to Martin Robertson, Cambridge Cambridgeshire; New York: Cambridge University Press. 
Pautasso A. 2015. La fille au pavot dans la coroplathie archaïque. Histoire et interprétations des relations symboliques, in: S. Huysecom-Haxhi, A. Muller (eds.) Figurines grecques en context. Presence muette dans le sanctuaire, la tombe et la maison, Lille: Presses Universitaires du Septentrion, 25-34.

Savel'eva E.S. 2018. Kult Afrodyty v Nikonii, in: I.V. Brujako, A.V. Glavenchuk (eds.), Antichnyj Nikonij i mir plemion Severo-Zapadnogo Prichernomor'ya. Materialy , kruglogo stola" posyashjonnogo jubileju N. M. Sekerskoj $n$ 60-letju nachala raskopok Nikonja (Odessa, 18 MYA 2017 G), Odessa, 36-49.
Schneider-Lengyel J. 1937. Griechische Terrakotten, Monachium: Bruckmann.

Uhlenbrock J.P. (ed.) 1990. The Coroplast's Art. Greek Terracottas of the Hellenistic World, Exposition Princeton-New Paltz-Cambridge 1990-1991, New York: State University of New York.

Vinitskaya G.G. 1951. Tekhnologicheskiye osnovy proizvodstva terrakot $v$ Ol'vii, Kratkie Soobshcheniya Instituta Arkheologii, vypusk 39, 3544.

Winter F. 1903. Die Typen der figürlichen Terrakotten I-II, Die antiken Terrakotten III, 1-2, Berlin.

Inga Gtuszek, $P h D$

RCID 0000-0003-0013-9785

Nicolaus Copernicus University in Torun

Faculty of History

Institute of Archaeology

ingag@umk.pl 